\title{
BACTERIA IN ANIMAL FEED AND THEIR SUSCEPTIBILITY TO ANTIMICROBIAL DRUGS ${ }^{1 *}$
}

\author{
Igor M. Stojanov², Milica M. Živkov Baloš, Miloš C. Kapetanov, \\ Jasna Z. Prodanov Radulović, Jelena M. Petrović \\ Scientific Veterinary Institute „Novi Sad“, Novi Sad, Serbia
}

\section{Abstract}

Control of microbiological safety of animal feed is regulated by a law. The regulation is based on methodological standards for estimation of feed quality. Those methods are permanently amended and strive for continuous improvement of microbiological safety of feed. The question remains whether the presence or absence of some bacterial species is sufficient for proper assessment of feed safety. The answer to this question can be found not only in the examination of the number of bacteria in animal feed, but also in qualitative analysis of the isolated microorganisms. The sensitivity of bacteria from animal feed to antimicrobials is one of the qualitative characteristics of microorganisms that can affect food safety even if the feed meets the standards and is within the maximum permitted level. The subject of our work was to determine the presence of bacteria in animal feed with a purpose to examine if they possess lower sensibility to antibiotics. For testing antibiotic sensitivity the isolates from routine microbiological feed control were used. The animal feed was analysed by the standard methods for the isolation and identification of bacteria and determination of susceptibility was done using disc diffusion method according to CLSI. The following bacteria were detected: Escherichia coli, Enterobacter sp., Staphylococcus sp., Micrococcus sp., Bacillus cereus, Bacillus sp. The results showed that some isolates have reduced susceptibility to certain antimicrobial drugs (The resistance is different for different antibiotics and microorganism - from 8,33\% to $100 \%$ ). This finding gives a reason for further examination of certain characteristics of the bacteria found in animal feed and to detect their possible influence on ecology.

Key words: animal feed, bacteria, antimicrobial drugs

\footnotetext{
${ }^{1}$ Research was financed by the Ministry of Science and Technological Development, Republic of Serbia, project TR 31071.

The article is presented at 6th Central European Congress on Food, May 23-26, 2012, Novi Sad, Serbia.

${ }^{2}$ E-mail: igor@niv.ns.ac.rs
} 


\title{
BAKTERIJE U STOČNOJ HRANI I NJIHOVA OSETLJIVOST NA ANTIMIKROBNE LEKOVE
}

\author{
Igor Stojanov, Milica Živkov Baloš, Miloš Kapetanov, \\ Jasna Prodanov Radulović, Jelena Petrović \\ Naučni institut za veterinarstvo „Novi Sad“, Novi Sad, Srbija
}

\section{Kratak sadržaj}

Kontrola mikrobiološke ispravnost stočne hrane je zakonom regulisana. Ova regulativa se oslanja na standarde u metodologiji ispitivanja stočne hane koji se permanentno menjaju u pravcu dograđivanja i poboljšanja ne samo metodologije već i indirektno same mikorbiološke bezbednosti namernica namenjenih životinja. Da li je samo prisustvo ili odsustvo pojednih bakterijskih vrsta dovoljno za pravilnu procenu bezbednosti hrane? Odgovor na pitanje može da se potraži ispitivanjem ne samo kvantitativnog prisustva bakterija u stočnoj hrani, već i kvalitativnim analizama prisutnih mikroorganizama. Osetljivost bakterija izolovanih iz stočne hrane prema antimikrobnim lekovima predstavlja jednu od kvalitativnih osobina mikroorganizama koja može uticati na kvalitet namirinica bez obzira što prema dozvoljenim graničnim vrednostima hranivo zadovoljava standarde. Predmet rada našeg istraživanja vezan je za praćenje prisustva bakterija u stočnoj hrani sa ciljem da se utvrdi da li je kod izolovanih bakterija prisutna smanjena osetljivost na antibiotike. Za proveru osetljivosti bakterija na antibakterijske lekove koristili smo izolate dobijene iz redovne mikrobiološke kontrole stočne hrane. Stočna hrana je obrađena standarnim metodama za izolaciju i identifikaciju bakterija a utvrđivanje osetljivosti izolata urađeno je metodom disk difuzije prema NCLS. Izolovane su sledeće bakterije: Escherichia coli, Enterobacter sp., Staphylococcus sp., Micrococcus sp., Bacillus cereus, Bacillus sp. Rezultati ispitivanja pokazuju prisustvo smanjene osetljivosti nekih izolata prema pojedinim antimikrobnim lekovima. Ovakav nalaz može dati odgovor na problem prisustva bakterija u stočnoj hrani, koji nije samo vezan za njihov broj, već i za njihove karakteristike koje mogu uticati na ekologiju mikroorganizama.

Ključne reči: stočna hrana, bakterije, antimikorbna osetljivost

\section{INTRODUCTION}

Different types of microorganisms can be found in feed. The microorganisms can be transmitted in different ways from the ground: by wind, rain and 
insects or by mechanical treatment (K.G. Maciorowski et al., 2007). Since the feed is the first critical point in the food production chain, it is necessary permanently to control the feed in terms of its safety. A detailed microbiological control of feed is described in the current legislation "Official Gazette" SFRJ 25/1980). This refers also to the methods of testing the total number of bacteria (TNB). In this way an entry of certain pathogens and zoonotic microorganisms in the feed is prevented. In indirect way, this ensures the microbiological safety of food of animal origin which can become a potential source of human infection. The standard methods for feed control and allowed limits in terms of number of saprophytic microorganisms are available.

The number of saprophytic microorganisms permitted by regulation is different depending on the type of feed and animal category for which the feed is intended. Legal acts determine only the quantity of saprophytic bacteria but the qualitative characteristics of saprophytes can be overlooked. On the other hand, saprophytes are living organisms that can posses some undesirable properties. They can also transfer some of their properties to microorganisms in the digestive tract of animals. A qualitative analysis of saprophytic bacteria can contribute in preventing the transfer of undesirable features. An example is the transfer of resistance genes to microbes that reside in animals. The increased selection of the resistant bacteria in animals and humans and the spread of genes that carry these characteristics may affect ecosystem (Leila Soufi et al., 2011). For these reasons, the subject of our research was related to monitoring the presence of bacteria in animal feed in order to determine whether the isolated bacteria posses the decreased sensitivity to antibiotics.

\section{MATERIAL AND METHODS}

Animal feed was analyzed for six months in the second half of 2011. The obtained samples originated from feed factories that regularly check their products. A total of 26 samples was examined for different animal categories. Total mix used in poultry fattening and grower of breeding hens (starter, grower, finisher), as well as the mix for calves and food supplements (vitamin and mineral, vitamin and protein) were examined. The samples were processed according to the methodology described in the Ordinance on the methods of performing microbiological analysis and super nutritional support life ("Official Gazette" SFRJ 25/1980). The samples were homogenized and weighed to $20 \mathrm{~g}$ in the Erlenmeyer flask bottle. A sterile physiological saline solution was added to the volume of $180 \mathrm{~mL}$ to obtain a basic dilution $10^{-1}$. From this dilution $1 \mathrm{ml}$ was taken and placed directly on blood agar (agar with 5\% defibrinated sheep blood) and McConkey agar. Identification of bacterial isolates was done 
after Gram stain and microscopic examination was performed by determining the physiological characteristics of bacteria through a series of biochemical tests (catalase test, Methyl red, indol producton, urease, citrate, mannitol fermentation) (Quinn et al., 2002). The sensitivity of isolated strains was done as recommended by CLSI (2006). We used antibiotic disks Tetracycline (30 $\mu \mathrm{g})$, ampicilline $(10 \mu \mathrm{g})$, streptomycin $(10 \mu \mathrm{g})$, Ceftriaxone $(30 \mu \mathrm{g})$, Trimethoprim + sulfamethoxazole (25 $\mu \mathrm{g}$ (trimetoprim 1,25 $\mu \mathrm{g}+$ sulamethox-azole $23.75 \mathrm{mg})$ ), chloramphenicol $(30 \mu \mathrm{g})$, lincomycin $(2 \mu \mathrm{g})$, enrofloxacin $(5 \mu \mathrm{g})$, amoxicillin (30 $\mu \mathrm{g}$ (amoxiciline $20 \mu \mathrm{g}+10 \mu \mathrm{g}$ clavulonic acid)) (produced by Bioanalyse) while Lincospectin $(109 \mu \mathrm{g}$ (lincomycin $9 \mu \mathrm{g}+$ Spektinomicin 100 $\mu \mathrm{g})$ discs were from the producer Bioanalyse, (Bioanalyse Ltd.).

\section{RESULTS AND DISCUSSION}

From a total of 26 processed materials 62 isolates were detected. Within the total number of isolated bacteria six different bacterial species were confirmed. Our study was limited to the obtained isolates and the sensitivity to antimicrobial drugs is given in Table 1.

Among Enterobacteriacae Escherichia coli and Enterobacter sp were most frequently found. These microorganisms were represented with $62.85 \%$ of total isolates. Bacillus sp., Staphylococcus sp. and Micrococcus sp. are microorganisms that are widespread in nature and are part of the saprophytic microbiota of humans, animals and the external environment. Flavobacter sp. belongs to a group of microorganisms that are found as commensals in the soil and their findings may indicate that the feed is contaminated and has been, directly or indirectly, in contact with bacteria of the soil.

The results showed that E. coli and Enterobacter sp. as the predominant microorganisms, contaminating feed, carry a high resistance to certain antimicrobial drugs. These two species showed complete resistance to lincomycin. This may be due to the long use of antimicrobial products as growth promoters or in prophylactic purposes (Frank M. Aarestrup, Henrik C.Wegener 1999; Torrence E. Mary, 2001). An extraordinary high resistance (75-100\%) to lincomycin and the fact that $50 \%$ or more isolates were resistant to ampicillin, amoxicillin and lincospectin is surprising since it is obvious that the strains isolated from food animals were in contact with the antimicrobial drugs long enough to develop resistance. Equally important would be to determine the sources of microorganisms from animal feed because of their high resistance to certain antimicrobial drugs that can occur only in contact with these agents or through horizontal transfer of the genome responsible for resistance (K.G. Maciorowski et al., 2007, Velhner Maja et al., 2010). The data obtained are 
similar to the study from Portugal (Paulo Martins da Costa et al., 2007) where the resistance in $E$. coli was relatively low (29.9\% ampicillin, tetracycline $27.7 \%$ ) or absent for amoxiclav. The study also shows that the resistance to three and more antibiotics was present in $18.1 \%$ of isolates.

Table 1. Sensitivity of isolated bacteria to antimicrobial therapy

\begin{tabular}{|l|c|c|c|c|c|c|c|c|c|}
\hline & \multicolumn{3}{|c|}{ E. coli } & \multicolumn{3}{c|}{ Enterobacter sp. } & \multicolumn{3}{c|}{ Bacillus sp. } \\
\hline & $\mathrm{S}(\%)$ & $\mathrm{I}(\%)$ & $\mathrm{R}(\%)$ & $\mathrm{S}(\%)$ & $\mathrm{I}(\%)$ & $\mathrm{R}(\%)$ & $\mathrm{S}(\%)$ & $\mathrm{I}(\%)$ & $\mathrm{R}(\%)$ \\
\hline 1. Tetracycline & 33.3 & 27.7 & 38.8 & 27.5 & 29.2 & 43.3 & 75 & 8.33 & 16.67 \\
\hline 2. Ampicillin & 33.3 & 11.1 & 55.5 & 26.4 & 19.1 & 54.5 & 41.66 & 16.67 & 41.66 \\
\hline 3. Streptomycin & 50 & 38.8 & 11.1 & 48.2 & 41.4 & 10.4 & 66.66 & 8.33 & 25 \\
\hline 4. Ceftriaxone & 100 & - & - & 91.3 & 8.7 & - & 50 & 8.33 & 41.66 \\
\hline 5. Trimetho.+sulf. & 100 & - & - & 93.5 & 6.5 & - & 33.33 & 16.66 & 50 \\
\hline 6. Chloramphenic. & 94.4 & - & 5.55 & 89.1 & 4.2 & 6.7 & 58.33 & 16.6 & 25 \\
\hline 7. Lyncomicin & - & - & 100 & - & - & 100 & 25 & - & 75 \\
\hline 8. Enrofloxascine & 100 & - & - & 100 & - & - & 91.66 & - & 8.33 \\
\hline 9. Amoxyclav. & 38.88 & 5.55 & 55.55 & 36.15 & 6.05 & 57.8 & 66.66 & - & 33.33 \\
\hline 10. Lyncospectino. & - & 44.44 & 55.55 & - & 39.15 & 60.85 & 25 & 41.66 & 33.33 \\
\hline
\end{tabular}

$\mathrm{S}$ - Sensitive, I - Intermediate, R - Resistant

Table 1. Sensitivity of isolated bacteria to antimicrobial therapy (continued)

\begin{tabular}{|l|c|c|c|c|c|c|c|c|c|}
\hline & \multicolumn{3}{|c|}{ Flavobacter sp. } & \multicolumn{3}{c|}{ Staphylococcus sp. } & \multicolumn{3}{c|}{ Micrococcus sp. } \\
\hline & $\mathrm{S}(\%)$ & $\mathrm{I}(\%)$ & $\mathrm{R}(\%)$ & $\mathrm{S}(\%)$ & $\mathrm{I}(\%)$ & $\mathrm{R}(\%)$ & $\mathrm{S}(\%)$ & $\mathrm{I}(\%)$ & $\mathrm{R}(\%)$ \\
\hline 1. Tetracycline & 100 & - & - & 83.3 & 16.6 & - & 91.6 & 8.4 & - \\
\hline 2. Ampicillin & 80 & - & 20 & 83.3 & 16.6 & - & 92.7 & 7.3 & - \\
\hline 3. Streptomycin & 80 & - & 20 & 83.3 & 16.6 & - & 82.9 & 17.1 & - \\
\hline 4. Ceftriaxone & 80 & - & 20 & 66.6 & 16.6 & 16,6 & 89.3 & 10.7 & - \\
\hline 5. Trimetho.+sulff. & 80 & 20 & - & 83.6 & - & 16,6 & 82.5 & 8.5 & 9 \\
\hline 6. Chloramphenic. & 100 & - & - & 83.3 & 16.6 & - & 83.3 & 16.6 & - \\
\hline 7. Lyncomicin & 20 & 40 & 40 & 42.8 & 28.63 & 28,57 & 50 & 38.3 & 11.7 \\
\hline 8. Enrofloxascine & 80 & 10 & - & 85.7 & 14.3 & - & 87.1 & 12.9 & - \\
\hline 9. Amoxyclav. & 80 & 20 & - & 85.7 & 14.3 & - & 75.8 & 24.2 & - \\
\hline 10. Lyncospectino. & 20 & 60 & 20 & 71.42 & - & 28.5 & 68.2 & 15.4 & 16.4 \\
\hline
\end{tabular}

$\mathrm{S}$ - Sensitive, I - Intermediate, R - Resistant

Microflora of the digestive tract contains hundreds of bacterial species ( $\mathrm{S}$. Steve Yan, Jeffrey M. Gilbert, 2004). The vertical transfer of resistance determinants can occur via plasmids, prophages, transposons and integrons (S. Steve Yan, Jeffrey M. Gilbert 2004, Velhner M. et al., 2010), especially among Gram 
negative bacteria. Subsequently drug-resistant strains can be transmitted from animals to humans. The presence of bacteria from the family Enterobacteriacae, such as E. coli and Enterobacter sp. in animal feed may contribute to the spread of resistance genes through horizontal or vertical transfer. This is why bacteria which is carrying resistance genes, become part of the microflora of the digestive tract (S. Steve Yan, Jeffrey M. Gilbert 2004). Also, resistance to some antimicrobial drugs can occur in herds that were not in contact with drugs during their lifetime. The presence of resistant strains of Flavobacter $s p$. in animal feeds confirms the possibility of transfer of soil bacteria to feed (K.G. Maciorowski et al., 2007). Also it has been observed that some resistance of Flavobacter to antimicrobial drugs may indicate that antibiotic substance came in soil where they have caused the appearance of resistance. On the other hand, it is possible that the emergence of resistance occurred as a result of the spread of bacteria among which the horizontal resistance gene transfer may happen.

\section{CONCLUSION}

Control of feed in respect to quantitative microbiological examination meets the standards that provide the limits of permissible and impermissible microorganisms. Our study has shown that the qualitative analysis of bacterial isolates contributed to a higher degree of food safety since it can provide information about the reduced sensitivity of bacteria to antimicrobial agents, a possible elimination from the food chain which leads to improvement of ecology.

\section{REFERENCES}

1. Clinical and Laboratory Standards Institute, 2006. Performance Standards for Antimicrobial Disk Susceptibility Tests; Approved Standard-Ninth Edition. Clinical and Laboratory Standards Institute document M2-A9 ŠISBN 1-56238-586-0C. Clinical and Laboratory Standards Institute, Wayne, Pa, USA.

2. Aarestrup F.M., Wegener H. C.: The effects of antibiotic usage in food animals on the development of antimicrobial resistance of importance for humans in Campylobacter and Escherichia coli, Microbes and Infection, Review, 1, 639-644, 1999

3. Soufi L., Sáenz Y., Vinué L., Abbassi M. S., Ruiz E., Zarazaga M., Hassen A. B., Hammami S., Torres C.: Escherichia coli of poultry food origin as reservoir of sulphonamide resistance genes and integrons, International Journal of Food Microbiology 144 , 497-502, 2011 
4. Maciorowski G.K., P. Herrera, F.T. Jones, S.D. Pillai, S.C Ricke:. Effects on poultry and livestock of feed contamination with bacteria and fungi, Animal Feed Science and Technology 133, 109-136, 2007

5. Costa P. M. da, Oliveira M., Bica A., Vaz-Pires P., Bernardo F.: Antimicrobial resistance in Enterococcus spp. and Escherichia coli isolated from poultry feed and feed ingredients, Veterinary Microbiology 120, 122-131, 2007

6. Quinn J. P., Markey, B., Carterr, E. M., Donnelly J.W., Leonard C.F.: Veterinary Microbiology and Microbial Diesaes; London: Mosby, 2002

7. Steve Yan S., Gilbert J. M... Antimicrobial drug delivery in food animals and microbial food safety concerns: an overview of in vitro and in vivo factors potentially affecting the animal gut microflora, Advanced Drug Delivery Reviews 56 , 1497-1521, 2004

8. Torrence E. M.: Activiets to address antimicrobial resistance in the United States, Preventive Veterinary Medicine 51, 37-49, 2001

9. Velhner M., Petrović J., Stojanov I., Ratajac R., Stojanović D.: Mehanizmi prenošenja rezistencije kod bakterija. Arhiv veterinarske medicine, 3, 1, 85-93, 2010

Primljeno: 10.08 .2012

Odobreno: 01.11.2012. 